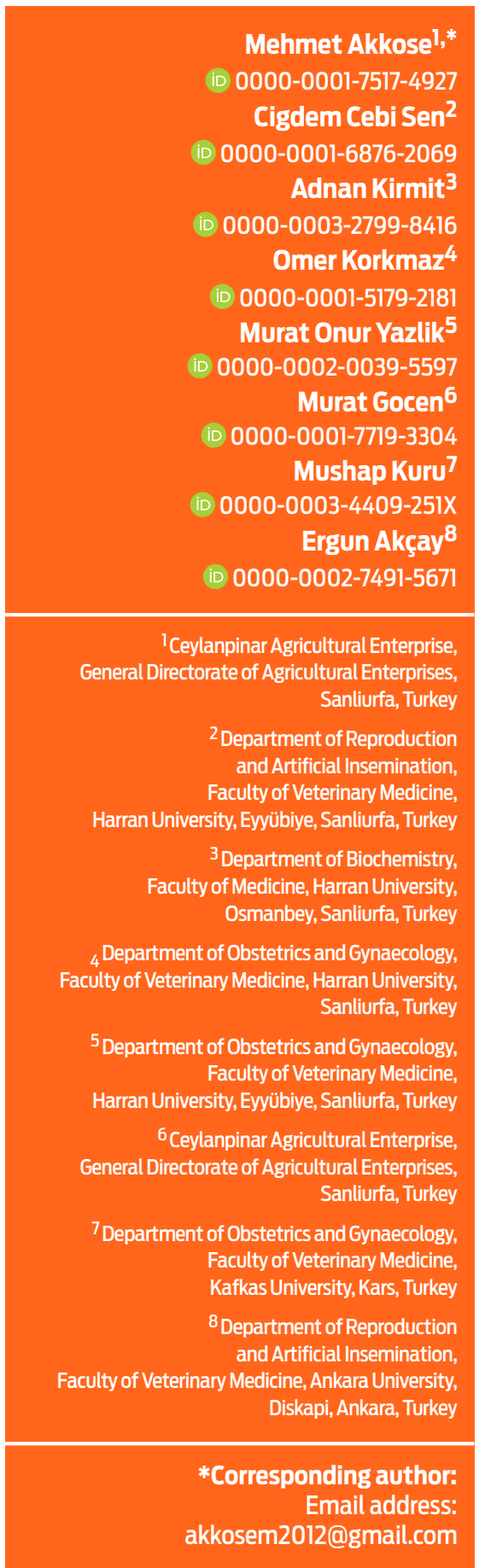

Accepted: 2019-06-18 Published: 2019-06-28

Additional information and declarations can be found on page 8

@) Copyright 2019 Mehmet Akkose et al.

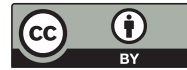

Distributed under Creative Commons CC-BY 4.0

\section{Pregnancy-associated glycoproteins (PAGs) and progesterone concentrations in Holstein heifers following two methods of estrus syncronization}

\begin{abstract}
Pregnancy-associated glycoproteins (PAGs) and progesterone concentrations were assessed in Holstein heifers 28 days post-insemination, following estrus synchronization with either a double prostaglandin (PG) injection or the ovsynch protocol. Animals between 15 and 20 months of age, with a 3-3.5 BCS, were randomly assigned to three groups: Heifers in the control group $(n=70)$ were monitored for estrus behaviour for 21 days and inseminated when detected in standing heat; Estrus of heifers in the Ovsynch group $(n=70)$ ) was synchronized following the Ovsynch protocol, and timed artificial insemination was performed $16 \mathrm{~h}$ after the completion of treatment; Animals in the PG group $(n=70)$ received two prostaglandin- $F_{2 \alpha}$ injections 11 days apart, were monitored for estrus behaviour for 2-5 days following the last injection, and inseminated when in heat. Serum PAGs and progesterone concentrations were measured in pregnant heifers (control group $n=25$; ovsynch group $n=22 ; P G$ group $n=21$ ) on day 28 after artificial insemination (Al). Mean serum PAGs concentrations (OD: optical density) were similar between groups (control $=3.37 \pm 0.148$, Ovsynch $=3.21 \pm 0.136$, and $P G=3.34 \pm 0.143 ; p>0.05)$. However, serum progesterone concentrations were found to be lower in the ovsynch group $(4.70 \pm 0.17 \mathrm{ng} / \mathrm{mL})$ when compared to the PG $(5.34 \pm 0.13 \mathrm{ng} / \mathrm{mL})$ or the control $(5.37 \pm 0.08$ $\mathrm{ng} / \mathrm{mL})$ groups $(\mathrm{p}<0.001)$. There was no correlation between serum PAGs and progesterone levels at day 28 post-insemination, or between early pregnancy PAGs concentrations and fetal death rates. Further research, including multiple sampling time points throughout gestation, after estrus synchronization protocols is warranted, to determine if there are associated temporal changes in PAGs and progesterone profiles that could impact reproductive parameters in dairy heifers.
\end{abstract}

Keywords: Heifer, PAGs, Ovsynch, PGF $_{2 \alpha^{\prime}}$ 'Progesterone

\section{Cite this as:}

Akkose M, Cebi-Sen C, Kirmit A, Korkmaz O, Yazlik MO, Gocen M, Kuru M, Akçay E. Pregnancy-associated glycoproteins (PAGs) and progesterone concentrations in Holstein heifers following two methods of estrus syncronization. Veterinaria México OA. 2019;2019(2). doi: 10.22201/fmvz.24486760e.2019.2.646. 


\section{Introduction}

Pregnancy-associated glycoproteins (PAGs) belong to the family of inactive aspartic proteinases. ${ }^{1}$ When first identified, they were known as pregnancy-specific protein B (PSPB), ${ }^{2}$ pregnancy-specific protein 60 (PSB-60) ${ }^{3}$ and Sheep Biology Unit-3 antigen (SBU). ${ }^{4}$ PAGs were definitely named by Zoli et al. ${ }^{5}$ after being isolated from bovine placentae, by means of a similar approach to that described by Butler et al. ${ }^{2}$ These glycoproteins are produced by ruminant trophoblasts and released into the intercotyledonary space, also reaching maternal circulation. PAGs are produced from the stage of embryo implantation and continue throughout gestation. ${ }^{6,7}$ In fact, PAGs are thought to be involved in maternal recognition of pregnancy. ${ }^{8}$ Presence of PAGs in maternal circulation allows for an early diagnosis of pregnancy,, 10 detection of late embryonic or early fetal deaths, identification of twin pregnancies, and monitoring of placental function. ${ }^{11,12}$ Also, early detection of non pregnant animals permitsa prompt reintoduction to appropriate reproductive management practices thereby reducing the calving interval. PAGs can be used for early diagnosis of pregnancy between days 26-30 post-insemination, since concentrations in maternal blood prior to this particular interval are highly variable and can thus jeopardize accuracy of test results. ${ }^{13}$ Factors that can affect serum PAGs concentrations are day of gestation, fetal number sire, milk production and season. ${ }^{14-16}$ To the authors' knowledge, the impact of different synchronization protocols on serum PAGs levels has not been investigated.

Development of synchronization protocols ensues a low efficiency of estrus behavior detection in large-scale enterprises. ${ }^{17}$ In dairy cattle, these protocols can include synchronization of oestrus and/ or of ovulation. Designed protocols are based on either shortening the luteal phase (via lysis of the corpus luteum with Prostaglandin $\mathrm{F}_{2 \alpha}\left[\mathrm{PGF}_{2 \alpha}\right]$ or its synthetic analogues), or lengthening diestrus (by use of exogenous progesterone or progestagens). ${ }^{17}$ When synchronization of ovulation is sought, both gonadotropin-releasing hormone $(\mathrm{GnRH})$ and prostaglandins are used. At present, there are several available GnRH based timed artificial insemination (TAl) protocols, ${ }^{18}$ the most commonly used being the ovsynch protocol. ${ }^{19}$ Reported pregnancy rates after implementation of an ovsynch protocol appear to be similar to those achieved after PGF estrus synchronization. ${ }^{20,21}$ However, fertility rates can be lower due to poor synchronization of ovulation in approximately one-third of ovsynch-treated cows ${ }^{18}$, and to ovulation of immature follicles. ${ }^{22,23}$ Moreover, GnRH-based synchronization protocols have been associated with lower pregnancy and higher embryonic death rates. ${ }^{18,23}$ This may relate to the stage of the oestrous cycle at which the GnRH-based protocol is initiated. ${ }^{24,25}$ Indeed, when $\mathrm{GnRH}$ was administered to cattle between days 1-4 or 14-21 of the estrous cycle, pregnancy rates were found to be lower than when given between days 5 and $13 .{ }^{24}$ In fact, when $\mathrm{GnRH}$ is administered during metestrus (Days 1 to 3 ), the dominant follicle may not ovulate, and hence undergo atresia at the established time for PGF injection. As for GnRH administration on days 13 to 17 of the estrous cycle, the dominant follicle of the second wave may also not ovulate, and luteolysis could result from endogenous PGF release, with a consequent early asynchronous ovulation regarding TAl, which results in low pregnancy rates. Moreover, Perry et al. ${ }^{23}$ reported that $\mathrm{GnRH}$-induced ovulation of physiologically immature follicles ( $<11 \mathrm{~mm}$ in diameter) was associated with lower blood estradiol levels on the day of insemination and a lower rate of increase of progesterone concentrations 
after insemination. However, follicle diameter has been shown to have no effect on fertility when the follicle is physiologically mature. ${ }^{23}$

Progesterone plays a critical role in conception, embryonic development, and pregnancy maintenance in cattle. ${ }^{26}$ In vitro research has shown that progesterone output is increased when PAGs are added to luteal cell cultures. ${ }^{27,28}$ Moreover, a positive correlation has been shown between serum level of PAGs and progesterone concentrations in dairy cattle, ${ }^{29,30}$ sheep, $^{31}$ and goats. ${ }^{32}$ Since low blood progesterone concentrations are associated with $\mathrm{GnRH}$-based protocols, we hypothesized that serum level of PAGs would also be low in ovsynch-treated heifers. Therefore, the present study aimed to assess 1) Any correlation between serum progesterone and PAGs concentrations at day 28 post-insemination, and 2) the effect of different synchronization methods on serum progesterone and PAGs concentrations on day 28 of pregnancy in dairy heifers.

\section{Materials and methods}

\section{Animals and experimental design}

This work was carried out between November 2016 and February 2017, at the Ceylanpinar Agricultural Enterprise in Turkey. The use of animals was approved by the Local Ethics and Animal Welfare Committee for Animal Research of DOLL-VET.

For this study, 210 reproductively sound and clinically healthy 15 to 20-month old Holstein heifers were used. All animals weighed between 340 and $400 \mathrm{~kg}$ and had a body condition score of 3.0-3.5. Heifers were kept in a semi-enclosed stall housing system, fed on a total mixed ration (TMR) (dry matter 90\%, metabolizable energy $2550 \mathrm{kcal} / \mathrm{kg}$, crude protein 16\%) and given ad libitum water. Vaccination against reproductive pathogens and treatment for internal and external parasites were administered at least 2 months prior to the set date for artificial insemination.

Synchronization protocols were started in all animals without previously establishing the stage of the estrous cycle. The presence of pre-ovulatory follicles and the lack of a corpus luteum were determined by rectal palpation and ultrasonography in heifers selected for Al. All inseminations were performed with proven fertile semen (obtained from the laboratory of the General Directorate of Agricultural Enterprises TiGEM, of the Ministry of Agriculture and Forestry), by an experienced veterinarian.

Heifers were randomnly allocated to three groups: Animals from the Control group ( $\mathrm{n}=70)$ did not receive any hormonal treatment, and were monitored for signs of estrous 2 to 3 times daily, for at least half an hour, for a 21-day period. Fifty heifers showing standing behavior, which was considered as the definite sign of estrus, were inseminated in this group. Animals in the Ovsynch group $(n=70)$, were synchronized with the Ovsynch protocol. ${ }^{19}$ Namely, $100 \mu$ g of gonadorelin diacetate tetrahydrate (GnRH, Ovarelin ${ }^{\circledR}$, Ceva Hayvan Sağlığı, Istanbul, Turkey) were administered to heifers by intramuscular (im) injection at the start of treatment (day 0), followed by $500 \mu \mathrm{g}$ of im cloprostenol sodium $\left(\mathrm{PGF}_{2 \alpha^{\prime}}\right.$ Juramate ${ }^{\circledR}$, Ege Vet Hayvancilık, Izmir, Turkey) on day 7, and a second $100 \mu \mathrm{G} \mathrm{GnRH}$ injection on day 9. Fixed-time artificial insemination was performed sixteen hours after treatment completion, only in heifers that had a preovulatory follicle and lacked a $\mathrm{CL}$, confirmed by examination of the ovaries $(n=52)$. Heifers in the PG group $(n=70)$ received two injections $500 \mu \mathrm{g}$ of $\mathrm{PGF}_{2 \alpha} 11$ days apart. Animals were observed for oestrus 
behaviour 2-5 days after the second $\mathrm{PGF}_{2 \alpha}$ injection, 2 to 3 times a day, for at least half an hour. Heifers showing signs of oestrus were artificially inseminated at the time of heat detection $(n=45)$.

\section{Blood sample collection}

Blood samples were collected from the coccygeal vein into dry vacuum tubes on day 28 post-Al. Samples were centrifuged at $3000 \mathrm{rpm}$ for 15 minutes for serum extraction, which was subsequently stored at $-20^{\circ} \mathrm{C}$ until assayed.

\section{Pregnancy diagnosis}

Pregnacy was diagnosed through identification of the embryonic vesicle and of the fetal heartbeat by transrectal ultrasonography (Hasvet 838) at day 28 postAl. Maintenance of pregnancy was subsequently confirmed by rectal palpation, through verification of slipping fetal membranes on days 60 and 90, and presence of placentomes or the foetus on day 120 .

\section{Measurement of serum PAGs and progesterone concentrations}

Serum PAGs concentrations were measured using a commercial ELISA kit (IDEXX Laboratories, Inc., Westbrook, ME, USA), at the laboratory of the distributor of the manufacturer in Turkey (Diagen Corp.), by a skilled technician and in accordance with the manufacturer's instructions. Briefly, an anti-PAG monoclonal antibody was coated onto a microtiter plate for the configuration of a plate format. This monoclonal antibody was produced against the PAG- 55 protein fraction, which is composed of PAG-4, PAG-6, PAG-9, PAG-16, PAG-18, and PAG-19.33 Once the diluted sample was incubated within the coated well, captured PAGs were detected with the aid of PAGs-specific antibodies (detector solution) and the horseradish peroxidase conjugate. After the unbound conjugate was washed away, 3,3', 5,5'-tetramethylbenzidine substrate was added to the wells. Colour reaction was measured with a spectrophotometer at a $450 \mathrm{~nm}$ wavelength. Result calculations were based on the optical density (OD minus background) of the samples. PAGs concentrations in a sample were determined by subtracting the mean $\mathrm{OD}$ value of the negative controls from the OD value obtained for each specific sample (S-N value), and proportionally relating the colour intensity to the amount of PAGs in the samples. There were two negative and two positive controls in each plate. ${ }^{16}$ Particularly, for pregnancy diagnosis through the PAGs assay, when the S-N value was $\geq 0.300$ the samples were deemed as positive (pregnant), and when the $\mathrm{S}-\mathrm{N}$ value was below 0.300 the samples were considered negative (nonpregnant). ${ }^{34}$

Serum progesterone concentrations were determined by a commercial bovine progesterone ELISA test kit (Wuhan Fine Biological Technology Co., Ltd., China), in accordance with the manufacturer's instructions. 


\section{Statistical analyses}

Differences in PAG and progesterone concentrations between groups were analyzed by one-way ANOVA and the Tukey's post-hoc test, using the SPSS ${ }^{\circledR}$ (SPSS 18.0, Chicago, IL, USA) software package. Normality of data was assessed by the Shapiro-Wilk's method. Results are expressed as mean \pm standard error (SE) of the mean. PAGs and progesterone correlations were determined by the Pearson's test. Pregnancy rates, conception rates and fetal death rates were analyzed by the chisquare test. Statistical significance was set at $p<0.05$. Pregnancy rate was defined as the percentage of pregnant animals from the total number of heifers within a group. The conception rate was considered as the percentage of animals determined to have conceived, from those that were artificially inseminated.

A positive diagnosis of pregnancy by transrectal ultrasonography was the reference test to which serum PAG test results were compared. The diagnostic value of the PAG ELISA used in this study was determined by establishing false positive(a), false negative (b), true positive (c) and true negative (d) results; and by subsequently calculating the sensitivity $[a /(a+c) \times 100]$, specificity $[d /(b+d) \times 100]$, positive predictive value (PPV) [a/( $a+b) \times 100]$, negative predictive value (NPV) [d/ $(d+c) \times 100]$, and accuracy of the test $[(a+d) /(a+b+d+c) \times 100]$.

\section{Results and discussion Conception and pregnancy rates}

Heifers in the control and PG groups were considered to be in estrus when displaying the distinctive standing behaviour. Estrus was detected in 71.4\% (50/70) and in 64.2\% (45/70) of the control and the PG group heifers respectively. All animals in the control and PG groups detected in heat were artificially inseminated, after the presence of a preovulatory follicle and the absence of a corpus luteum were confirmed by rectal palpation and ultrasonography of the ovaries. Verification of these same ovarian characteristics was necessary to consider that a heifer from the ovsynch group positively responded to the synchronization protocol. Following this confirmation, $74.3 \%$ (52/70) of the animals in this last group were inseminated $16 \mathrm{~h}$ after treatment completion. Accordingly, Colazo et al. ${ }^{35}$ reported that $11 \%$ of the cattle ovulated before TAI and 15\% did not respond to PGF injection after using an ovsynch protocol for estrus synchronization.

Conception (Control 50\% Ovsynch 42\% and PG 47\%) and pregnancy (Control 36\%, Ovsynch $31 \%$ and PG 30\%) rates determined on day 28 post-Al, did not differ between groups ( $p>0.05$; Table 1).

There are reports of similar conception and pregnancy rates after natural breeding or $\mathrm{Al}$ in synchronized cows using either a double injection of $\mathrm{PGF}_{2 \alpha}$ or the ovsynch protocol. ${ }^{20,36-38}$ However, lower percentages of both parameters have been reported after natural presentation or synchronization of estrus in cattle, due to inefficient heat detection or early embryo deaths. ${ }^{39}$ Hence, the lack of difference found for conception or pregnancy rates between groups in this study may have resulted from an absence of impact of the synchronization protocols on reproductive parameters, or it could derive from a decreased statistical power due to the low number of included observations. 
Table 1. Pregnancy and conception rates of non-synchronized and synchronized heifers on Day 28 post-Al.

\begin{tabular}{|c|c|c|c|c|c|}
\hline Group & N & $\begin{array}{c}\text { Number of artificially } \\
\text { inseminated animals }\end{array}$ & $\begin{array}{c}\text { Number of } \\
\text { pregnant animals }\end{array}$ & $\begin{array}{c}\text { Pregnancy rate* } \\
\%\end{array}$ & $\begin{array}{c}\text { Conception rate*** } \\
\%\end{array}$ \\
\hline Control & 70 & 50 & 25 & 36 & 50 \\
\hline Ovsynch & 70 & 52 & 22 & 31 & 42 \\
\hline PG & 70 & 45 & 21 & 30 & 47 \\
\hline P value & & & & $>0.05$ & $>0.05$ \\
\hline
\end{tabular}

* Pregnancy rate: pregnant heifers/total number of heifers within a group.

** Conception rate: pregnant heifers/artificially inseminated heifers.

\section{Serum PAGs and Progesterone concentrations}

PAGs concentrations (OD) were found to be different between pregnant $(3.31 \pm 0.07)$ and non-pregnant $(0.12 \pm 0.02)$ heifers $(p<0.001)$. However, no differences were found between treatment groups in pregnant animals (Control $3.37 \pm 0.15, \mathrm{n}=25$; Ovsynch $3.21 \pm 0.14 \mathrm{n}=22$ and PG $3.34 \pm 0.15, \mathrm{n}=21$ ) $(p>0.05)$. Other studies have also found similar PAGs concentrations in dairy heifers during the 4th week of gestation using the same commercial PAG ELISA test kit. ${ }^{34}$

Serum progesterone concentrations of the pregnant heifers in the Ovsynch Group were lower $(4.70 \pm 0.17 \mathrm{ng} / \mathrm{mL})$ than those found in the control $(5.37 \pm 0.08 \mathrm{ng} / \mathrm{mL})$, or the PG $(5.34 \pm 0.13 \mathrm{ng} / \mathrm{mL})$ groups $(p<0.001$; Figure 1). There are reports that suggest that $\mathrm{GnRH}$-based protocols are associated with low blood progesterone concentrations. ${ }^{23}$ Nevertheless, the lower levels of progesterone found for the Ovsynch group in this study fell within established values for early gestation in cattle ${ }^{40}$, and did not have an impact on conception, pregnancy or fetal death rates.

No correlation was found between mean serum PAGs and progesterone concentrations on day 28 post-Al $(r=0.024, p=0.85)$. While some authors state that blood PAGs and progesterone concentrations are not correlated, ${ }^{14,15,41}$ others suggest that PAGs levels may positively impact serum progesterone. ${ }^{29-32}$ In fact, in vitro research has revealed that the administration of PAGs to luteal cell cultures may increase progesterone output by these cells. ${ }^{27,28}$ Conversely, above average progesterone concentrations on day 21 of gestation have also been related to an increased PAGs level through the first trimester of pregnancy in dairy cattle. ${ }^{29}$ The correlation between PAGs and progesterone was assessed in the present study using relatively few samples, which were taken at a single time point. Further research that considers multiple sampling time points and a higher number of animals may yield more accurate results.

\section{Diagnostic characteristics of the serum PAG-ELISA test}

The PAGs ELISA test was used to distinguish between pregnant and non-pregnant animals and to calculate relative PAGs concentrations in sera of inseminated heifers. Values for sensitivity, specificity, PPV, NPV and accuracy of the test on day 28 post-IA were 100\%, 94,9\%, 94,4\%, 100\% and 97,3\%, respectively. Our test re- 


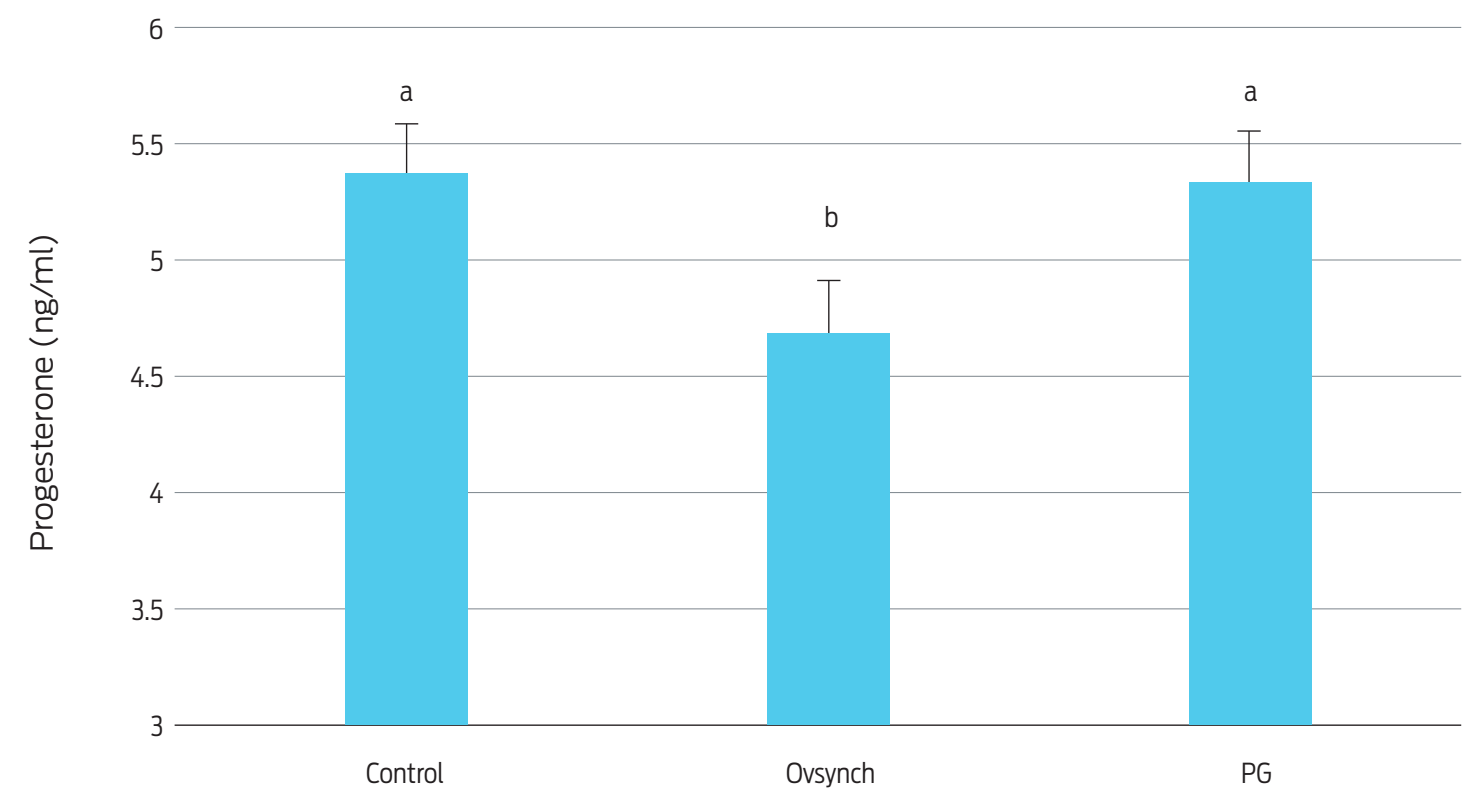

Figure 1. Mean progesterone concentrations on control and synchronized heifers on day 28 of pregnancy. $\mathrm{a}, \mathrm{b}$ Different superscripts indicate differences between groups $(p<0.001)$.

sults agree with those obtained in previously conducted studies that used a similar assay in the 4th and 5th weeks of cattle pregnancy. ${ }^{16,34,42}$

\section{Embryo and fetal death rates}

Reproductive performance of a cattle herd can be heavily impacted by embryo and fetal deaths. Both embryonic and fetal death rates have been found to increase when $\mathrm{GnRH}$-based estrus synchronization protocols are used in cattle. ${ }^{22,23}$ In the present study, there were no embryo or fetal deaths at days 28,60 or 90 of pregnancy. However, examinations for pregnancy confirmation at day 120 revealed two fetal losses in the control group (8\%), one in the Ovsynch group (4.5\%), and one in the PG group (4.8\%). The overall rate of fetal death at this time point was 5.9\% with no differences found between groups ( $p>0.05)$.

Low plasma PAGs concentrations during early pregnancy have been related to early embryonic and late fetal deaths in cows. ${ }^{16,43-47}$ The mean serum PAGs and progesterone concentrations on day 28 in heifers that lost their calf at day 120 of pregnancy in this study were $3.79 \pm 0.19$ and $5.53 \pm 0.21 \mathrm{ng} / \mathrm{ml}$, respectively, which were similar to obtained values for heifers that completed their pregnancies (3.24 \pm 0.09 and $5.11 \pm 0.09 \mathrm{ng} / \mathrm{ml}$, respectively; p > 0.05).

\section{Conclusion}

Serum progesterone concentrations in early pregnancy were found to be lower in synchronized dairy heifers with the Ovsynch protocol. However, no differences were observed between treatment groups regarding serum PAGs concentrations at day 28 of gestation. Furthermore, no correlation was detected between serum 
PAGs and progesterone levels, or between PAGs concentrations in early pregnancy and fetal deaths on day 120 of pregnancy. Further research including multiple sampling time points throughout gestation is warranted to determine changes in PAGs and progesterone profiles, their temporal correlation, and if there is a related impact on embryo or fetal death in dairy heifers.

\section{Acknowledgements}

We thank the General Directorate of Agricultural Enterprises for granting permission to conduct this study at their farm. Also, we would like to thank the Scientific Research Council of Harran University (HUBAK, project No. 17060) for partial financial support of this study.

\section{Conflicts of interest}

The authors declare that they have no conflict of interest.

\section{Author contributions}

M.A. designed and performed experiments, analyzed data, drafted document, wrote the final paper; C.C.-S. designed and performed experiments, wrote the final paper; A.K. performed experiments; O.K. performed experiments, wrote the final paper; M.O.Y. drafted document, wrote the final paper; M.G. performed experiments; M.K. analyzed data; E.A. wrote the final paper.

\section{References}

1. Hughes AL, Green JA, Piontkivska H, Roberts RM. Aspartic proteinase phylogeny and the origin of pregnancy-associated glycoproteins. Mol Biol Evol. 2003;20(11):1940-5.

2. Butler JE, Hamilton WC, Sasser RG, Ruder CA, Hass GM, Williams RJ. Detection and partial characterization of two bovine pregnancy-specific proteins. Biol Reprod. 1982;26(5):925-33.

3. Mialon MM, Camous S, Renand G, Martal J. Menissier F. Peripheral concentrations of a $60-\mathrm{kDa}$ pregnancy serum protein during gestation and after calving and in relationship to embryonic mortality in cattle. Reprod Nutr Dev. 1993;33(3):269-82.

4. Atkinson YH, Gogolin-Ewens KJ. Hounsel EF, Davies MJ, Brandon MR, Seamark RF. Characterization of placentation-specific binucleate cell glycoproteins possessing a novel carbohydrate. J Biol Chem. 1993;268(35):26679-85.

5. Zoli AP, Guilbault LA, Delahaut P, Ortiz WB, Beckers JF. Radioimmunoassay of a bovine pregnancy-associated glycoprotein in serum: its application for pregnancy diagnosis. Biol Reprod. 1992;46(1):83-92.

6. Sousa NM, Ayad A, Beckers JF, Gajewski Z. Pregnancy-associated glycoproteins (PAG) as pregnancy markers in the ruminants. J Physiol Pharmacol. 2006;57 Suppl 8:153-71.

7. Cain AJ, Christiansen D. Biochemical pregnancy diagnosis. In: Hopper RM, editor. Bovine reproduction. 1st ed. Pondicherry, India: Wiley Blackwell; 2015. p. 320-5. 
8. Egen $T E$, Ealy $A D$, Landon $D A$, Roberts RM, Green JA. Autoimmunization of ewes against pregnancy-associated glycoproteins does not interfere with the establishment and maintenance of pregnancy. Animal. 2009;3(6):850-7.

9. Balhara AK, Gupta M, Singh S, Mohanty AK, Singh I. Early pregnancy diagnosis in bovines: current status and future directions. ScientificWorldJournal. 2013;2013:1-10.

10. Akköse M, Cebi-Sen C. Sütçü sığıllarda erken gebelik tanısı. Hay Uret. 2019. In press.

11. Pohler KG, Gatea AO, Peres RFG, Pereira MHC, Vasconcelos JLM. Application of pregnancy associated glycoproteins (PAGs) to improve reproductive efficiency in cattle. Clinical Theriogenology. 2015;7(3):215-21.

12. Wallace RM, Pohler KG, Smith MF, Green JA. Placental PAGs: Gene origins, expression patterns, and use as markers of pregnancy. Reproduction. 2015;149(3):115-26.

13. Fricke PM, Ricci A, Giordano JO, Carvalho PD. Methods for and implementation of pregnancy diagnosis in dairy cows. Vet Clin North Am Food Anim Pract. 2016;32(1):165-80.

14. Serrano B, López-Gatius F, Santolaria P, Almería S, García-Ispierto I, Bech-Sabat $\mathrm{G}$, et al. Factors affecting plasma pregnancy-associated glycoprotein 1 concentrations throughout gestation in high-producing dairy cows. Reprod Dom Anim. 2009;44(4):600-5.

15. López-Gatius F, Garbayo JM, Santolaria P, Yaniz J, Ayad A, deSousa NM, et al. Milk production correlates negatively with plasma levels of pregnancy-associated glycoprotein (PAG) during the early fetal period in high producing dairy cows with live fetuses. Domest Anim Endocrinol. 2007;32(1):29-42.

16. Ricci A, Carvalho PD, Amundson MC, Fourdraine RH, Vincenti L, Fricke PM. Factors associated with pregnancy-associated glycoprotein (PAG) levels in plasma and milk of Holstein cows during early pregnancy and their effect on the accuracy of pregnancy diagnosis. J Dairy Sci. 2015;98(4):2502-14.

17. Kasimanickam R. Pharmacological intervention of estrus cycles. In: Hopper RM, editor. Bovine reproduction. 1st ed. Pondicherry, India: Wiley Blackwell; 2015.p. 304-13.

18. Colazo MG, Mapletoft RJ. A review of current timed-Al (TAI) programs for beef and dairy cattle. Can Vet J. 2014;55(8):772-80.

19. Pursley JR, Mee MO, Wiltbank MC. Synchronization of ovulation in dairy cows using PGF2alpha and GnRH. Theriogenology. 1995;44(7):915-23.

20. Rabiee AR, Lean IJ, Stevenson MA. Efficacy of ovsynch program on reproductive performance in dairy cattle. A meta analysis. J Dairy Sci. 2005;88(8):2754-70.

21. Bisinotto RS, Ribeiro ES, Santos JEP. Synchronisation of ovulation for management of reproduction in dairy cows. Animal. 2014;8(1):151-9.

22. Vasconcelos JLM, Sartori R, Oliveira HN, Guenther JG, Wiltbank MC. Reduction in size of the ovulatory follicle reduces subsequent luteal size and pregnancy rate. Theriogenology. 2001;56(2):307-14.

23. Perry GA, Smith MF, Lucy MC, Green JA, Parks TE, MacNeil MD, et al. Relationship between follicle size at insemination and pregnancy success. PNAS. 2005;102(14):5268-73.

24. Vasconcelos JLM, Silcox RW, Pursley JR, Wiltbank MC. Synchronization rate, size of the ovulatory follicle, and pregnancy rate after synchronization of ovulation 
beginning on different days of the estrous cycle in lactating dairy cows. Theriogenology. 1999;52(6):1067-78.

25. Moreira F, de la Sota RL, Diaz T, Thatcher WW. Effect of day of the estrous cycle at the initiation of a timed artificial insemination protocol on reproductive responses in dairy heifers. J Anim Sci. 2000;78(6):1568-76.

26. Wiltbank MC, Souza AH, Giordano JO, Nascimento AB, Vasconcelos JM, Pereira $\mathrm{MHC}$, et al. Positive and negative effects of progesterone during timed Al protocols in lactating dairy cattle. Anim Reprod. 2012;9(3):231-41.

27. Del Vecchio RP, Sutherland WD, Sasser RG. Bovine luteal cell production in vitro of prostaglandin E2, oxytocin and progesterone in response to pregnancy-specific protein B and prostaglandin F2 alpha. J Reprod Fertil. 1996;107(1):131-6.

28. Weems YS, Lammoglia MA, Vera-Avila HR, Randel RD, King C, Sasser RG, et al. Effect of luteinizing hormone (LH), PGE2, 8-EPI-PGE1, 8-EPI-PGE2, trichosanthin, and pregnancy specific protein $B$ (PSPB) on secretion of progesterone in vitro by corpora lutea $(\mathrm{CL})$ from nonpregnant and pregnant cows. Prostaglandins Other Lipid Mediat. 1998;55(1):27-42.

29. Ayad A, Sousa NM, Sulon J, Hornick JL, Watts J, Lopez-Gatius F, et al. Influence of progesterone concentrations on secretory functions of trophoblast and $\mathrm{pi}$ tuitary during the first trimester of pregnancy in dairy cattle. Theriogenology. 2007;67(9):1503-11.

30. Barbato O, Merlo M, Celi P, Sousa NM, Guarneri L, Beckers JF, et al. Relationship between plasma progesterone and pregnancy-associated glycoprotein concentrations during early pregnancy in dairy cows. Vet J. 2013;195(3):385-7.

31. Roberts JN, May KJ, Veiga-Lopez A. Time-dependent changes in pregnancy-associated glycoproteins and progesterone in commercial crossbred sheep. Theriogenology. 2017;89:271-9.

32. Tandiya U, Nagar V, Yadav VP, Ali I, Gupta M, Dangi SS, et al. Temporal changes in pregnancy-associated glycoproteins across different stages of gestation in the Barbari goat. Anim Reprod Sci. 2013;142(3-4):141-8.

33. Nagappan $M$, McGrath $M$, Schenkel R. Inventors. Methods for early detection of pregnancy in cows. Monsanto Technology LLC, assignee. 2009; US Pat. No. 7,604,950 B2 22.

34. Kaya MS, Köse M, Bozkaya F, Mutlu H, Uçar EH, Atlı MO. Early pregnancy diagnosis using a commercial ELISA test based on pregnancy-associated glycoproteins in Holstein-Friesian heifers and lactating cows. Turk J Vet Anim Sci. 2016;40(6):1-6.

35. Colazo MG, Gordon MB, Rajamahendran R, Mapletoft RJ, Ambrose DJ. Pregnancy rates to timed-Al in dairy cows treated with gonadotropin-releasing hormone or porcine luteinizing hormone. Theriogenology. 2009;72(2):262-70.

36. Gumen A, Guenther JN, Wiltbank MC. Follicular size and response to ovsynch versus detection of estrus in anovular and ovular lactating dairy cows. J Dairy Sci. 2002;86(10):3184-94.

37. Stevenson JS, Kobayashi Y, Thompson KE. Reproductive performance of dairy cows in various programmed breeding systems including OvSynch and combinations of gonadotropin-releasing hormone and prostaglandin $\mathrm{F}_{2 \mathrm{a}}$.J Dairy Sci. 1999;82(3):506-15. 
38. Tenhagen BA, Drillich M, Heuwieser W. Analysis of cow factors influencing conception rates after two timed breeding protocols. Theriogenology. 2001;56(5):831-8.

39. Bartolome LA, Archbald LF. Reproductive management in dairy cows. In: Risco CA, Melendez P, editors. Dairy production medicine. 1st ed. London: Wiley Blackwell; 2011. p. 73-80.

40. Taverne MA, Noakes DE. Pregnancy and its diagnosis. In: Noakes DE, Parkinson DJ, England GCW, editors. Veterinary reproduction and obstetrics. 9th ed. London: Saunders Elsevier; 2009. p. 76-122.

41. Lobago F, Bekana M, Gustafsson H, Beckers JF, Yohannes G, Aster Y, et al. Serum profiles of pregnancy-associated glycoprotein, oestrone sulphate and progesterone during gestation and some factors influencing the profiles in Ethiopian Borana and crossbred cattle. Reprod Domest Anim. 2009;44(4):685-92.

42. Silva E, Sterry RA, Kolb D, Mathialaghan N, McGrath MF, Ballam JM, et al. Accuracy of a pregnancy-associated glycoprotein ELISA to determine pregnancy status of lactating dairy cows twenty-seven days after timed artificial insemination. J Dairy Sci. 2007;90(10):4612-22.

43. López-Gatius F, Hunter RH, Garbayo JM, Santolaria P, Yániz J, Serrano B, et al. Plasma concentrations of pregnancy-associated glycoprotein-1 (PAG-1) in high producing dairy cows suffering early fetal loss during the warm season. Theriogenology. 2007;67(8):1324-30.

44. Pohler KG, Geary TW, Johnson CL, Atkins JA, Jinks EM, Busch DC, et al. Circulating bovine pregnancy associated glycoproteins are associated with late embryonic/fetal survival but not ovulatory follicle size in suckled beef cows. J Anim Sci. 2013;91(9):4158-67.

45. Pohler KG, Pereira MH, Lopes FR, Lawrence JC, Keisler DH, Smith MF, et al. Circulating concentrations of bovine pregnancy-associated glycoproteins and late embryonic mortality in lactating dairy herds. J Dairy Sci. 2016;9(2):1584-94.

46. Pohler KG, Peres RF, Green JA, Graff H, Martins T, Vasconcelos JL, et al. Use of bovine pregnancy-associated glycoproteins to predict late embryonic mortality in postpartum Nelore beef cows. Theriogenology. 2016;85(9):1652-9.

47. Breukelman SP, Perényi Z, Taverne MA, Jonker H, van der Weijden GC, Vos PL, de Ruigh $L$, et al. Characterisation of pregnancy losses after embryo transfer by measuring plasma progesterone and bovine pregnancy-associated glycoprotein-1 concentrations. Vet J. 2012;194(1):71-6. 